\title{
Stimulation of fibronectin production and deposition by chicken granulosa cells in vitro by epidermal growth factor and transforming growth factor $\alpha$
}

\author{
E. K. Asem and R. P. Novero \\ Department of Physiology and Pharmacology, School of Veterinary Medicine, \\ Purdue University, West Lafayette, IN 47907, USA
}

\begin{abstract}
Experiments were conducted in vitro to examine the effect of epidermal growth factor (EGF) and transforming growth factor $\alpha$ (TGF- $\alpha$ ) on the production of fibronectin (deposited, secreted into medium and cell-associated) by hen granulosa cells isolated from the largest $\left(\mathrm{F}_{1}\right.$; about $35 \mathrm{~mm}$ in diameter, mature) and third largest $\left(\mathrm{F}_{3} ; 15-20 \mathrm{~mm}\right.$ in diameter) preovulatory follicles, as well as from a pool of immature small yellow follicles $(6-8 \mathrm{~mm}$ in diameter). The cells were incubated in culture wells coated with type IV collagen or in wells without collagen coating, and the amounts of fibronectin produced were measured using a specific ELISA. The total amount of fibronectin produced by unstimulated cells was greatest in wells containing $\mathrm{F}_{1}$ cells and increased with time. The amount of fibronectin deposited by unstimulated cells was greatest in wells containing $F_{1}$ cells and was much higher in collagen-coated wells than in uncoated wells. Both EGF and TGF- $\alpha$ increased the quantity of fibronectin deposited by granulosa cells in collagen-coated and uncoated wells. Fibronectin secreted into the medium by unstimulated cells also increased with the stage of follicular maturation and was enhanced by EGF and TGF- $\alpha$. The quantity of cell-associated fibronectin in granulosa cells in collagen-coated and uncoated wells was also increased by these growth factors. Type IV collagen did not have any appreciable effect on the amount of fibronectin present in the incubation medium or on cell-associated fibronectin. Because of its marked effect on deposited fibronectin, there were greater total quantities of fibronectin in culture wells coated with type IV collagen. These results demonstrate that EGF and TGF- $\alpha$ stimulate the production and deposition of fibronectin by chicken granulosa cells. The results also suggest that in combination with collagen IV, these growth factors can regulate the formation of the extracellular matrix (for example, basal lamina) of the hen ovarian follicle.
\end{abstract}

\section{Introduction}

The amount of the extracellular matrix glycoprotein, fibronectin, has been shown to increase in tissues that are undergoing modification (physiological or pathological), such as during embryogenesis (Linder et al., 1975; Critchley et al., 1979), inflammation (Fyrand, 1980; Clark et al., 1981), tumour growth (Kimata et al., 1982; Grimwood et al., 1984), or wound repair (Kurkinen et al., 1980; Grinnell et al., 1981). Fibronectin binds to cell surfaces and biological materials (for example, collagen) simultaneously and influences the attachment, morphology and growth of cells (Klebe, 1974; Pearlstein, 1976). It is produced by bovine (Savion and Gospodarowicz, 1980; Bernath et al., 1990), rat (Skinner et al., 1985; Dorrington and Skinner, 1986; Carnegie, 1990), and chicken (Asem et al., 1992, 1994; Asem and Novero, 1993a, b; Novero and Asem, 1993) ovarian granulosa cells in vitro. Fibronectin has been immunolocalized to the basal lamina (a basement membrane) of chicken

Received 3 November 1993
(Yoshimura et al., 1985; Callebaut et al., 1988), rat (Bagavandoss et al., 1983) and bovine (Yoshimura and Okamoto, 1991) ovarian follicles. Basement membranes are extracellular matrices that perform a wide variety of functions such as molecular filtration, adhesion, cellular growth, and differentiation during important physiological processes.

The differentiation of rat and pig granulosa cells is influenced to a large extent by growth factors such as epidermal growth factor (EGF; Hsueh et al., 1981; Schomberg et al., 1983; May et al., 1988; Bendell and Dorrington, 1990), transforming growth factor $\alpha$ (TGF- $\alpha$; Adashi et al., 1987), transforming growth factor $\beta$ (May et al, 1988), and insulin-like growth factor I (May et al., 1988; Roy and Greenwald, 1991), with pronounced effects on DNA synthesis (Hammond and English, 1987; May et al., 1988). The differentiation of hen granulosa cells is accompanied by the production of large quantities of progesterone (Hammond et al., 1981; Asem et al., 1983; Bahr et al., 1983; Etches and Duke, 1984; Marrone and Hertelendy, 1983).

Fibronectin is produced by chicken granulosa cells in vitro such that the amount produced is increased with advancing 
stages of follicular maturation (Asem et al., 1992; Novero and Asem, 1993). Recent studies have demonstrated that EGF and TGF- $\alpha$ control the transcription of genes encoding enzymes involved in steroid-hormone biosynthesis in hen granulosa cells ( $\mathrm{Li}$ and Johnson, 1993). Because both fibronectin and steroid-hormone biosynthesis and secretion by hen granulosa cells are influenced by the stage of follicular development, and because EGF and TGF- $\alpha$ regulate the expression of steroidogenic enzymes in immature hen granulosa cells, it was hypothesized that these growth factors regulate fibronectin production by hen granulosa cells. The aim of the present study was to examine the effect of EGF and TGF- $\alpha$ on fibronectin production by hen granulosa cells, especially those obtained from immature, small yellow follicles $(6-8 \mathrm{~mm}$ in diameter). Because fibronectin interacts with other macromolecules that participate in the structural organization of basement membranes (Ruoslahti et al., 1981; Hynes and Yamada, 1982), and because type IV collagen is a major (and unique) component of basement membranes (Timpl, 1989; Yurchenco and Schittny, 1990), experiments were also designed to assess the effect of this type of collagen on fibronectin production by hen granulosa cells.

\section{Materials and Methods}

\section{Hormones and chemicals}

Mouse submaxillary gland EGF and synthetic TGF- $\alpha$ were obtained from ICN Biochemicals (Irvine, CA). Hepes, collagenase Type $1 \mathrm{~A}$, soybean trypsin inhibitor, BSA (Fraction V), leupeptin, phenylmethylsulfonyl fluoride (PMSF), Triton X-100, pepstatin, EDTA-Na, penicillin $\mathrm{G}$, streptomycin, and fungizone were purchased from Sigma Chemical Co. (St Louis, MO). Medium 199 containing Hank's salts was from Gibco-BRL (Grand Island, NY). Fibronectin standard (purified human fibronectin) and rabbit anti-chicken fibronectin serum were purchased from Chemicon International (Temecula, CA). Immulon 2 microtitre plates were obtained from Dynatech Laboratories (Chantilly, VA). Peroxidase-conjugated goat anti-rabbit immunoglobulin $\mathrm{G}(\mathrm{IgG})$ and 2,2'-azino-di-3ethylbenzthiazoline sulfonate were purchased from BoehringerMannheim (Indianapolis, IN). Falcon 96-well plates (uncoated) and coated with mouse type IV collagen were purchased from Collaborative Biomedical Products, Becton Dickinson Labware (Bedford, MA).

\section{Animals, collection of follicles and isolation of granulosa cells}

Single-comb White Leghorn hens in their first year of reproductive activity (obtained from Purdue Baker Farms, West Lafayette, IN) were caged individually in a windowless, ventilated room under a photoperiod of $14 \mathrm{~h}$ light: $10 \mathrm{~h}$ dark. The birds had free access to a layer ration and tap water. The time of daily egg lay of each bird was noted to the nearest $30 \mathrm{~min}$. They were killed by cervical dislocation 10-14 $\mathrm{h}$ before the expected time of ovulation of the largest preovulatory follicle. The granulosa cell layer from the largest preovulatory follicle $\left(\mathrm{F}_{1}\right.$, about $35 \mathrm{~mm}$ in diameter, mature $)$ and the third largest preovulatory follicle $\left(F_{3}, 15-20 \mathrm{~mm}\right.$ in diameter, developing) were separated from the theca layer as described by Gilbert et al. (1977). The immature small yellow follicles were placed in a $60 \mathrm{~mm}$ Petri dish containing $\mathrm{I}-2 \mathrm{ml}$ ice-cold saline. A $3-5 \mathrm{~mm}$ cut was made in the wall of the follicle and the yolk allowed to fall out. While holding one edge of the thecal layer with fine forceps, the follicular wall was shaken gently in the saline to release the granulosa cell layer. The granulosa cells from all types of follicle were dissociated in Medium 199 (with Hank's salts) containing $10 \mathrm{mmol}$ Hepes $1^{-1}, \mathrm{pH} 7.4,500 \mathrm{U}$ collagenase $\mathrm{ml}^{-1}, 0.2 \mathrm{mg}$ trypsin inhibitor $\mathrm{ml}^{-1}, 100000 \mathrm{U}$ penicillin $G 1^{-1}, 100 \mathrm{mg}$ streptomycin $\mathrm{l}^{-1}$, and $250 \mu \mathrm{g}$ fungizone $\mathrm{l}^{-1}$ (Novero and Asem, 1993). Cell viability, determined by the trypan blue exclusion method, was routinely greater than $95 \%$ for cells obtained from the $\mathrm{F}_{1}$ follicles and greater than $90 \%$ for cells obtained from the $\mathrm{F}_{3}$ follicles or from small yellow follicles. Follicles were classified according to the criteria of Robinson and Etches (1986).

\section{Experiments}

The granulosa cells were plated at a density of 1.0$2.0 \times 10^{5}$ live cells $\mathrm{ml}^{-1}$ in 96-well Falcon plates, and incubated at $37^{\circ} \mathrm{C}$ in serum-free Medium 199 (with Hank's salts) buffered with $10 \mathrm{mmol}$ Hepes $1^{-1}(\mathrm{pH} 7.4)$ and supplemented with $0.1 \%(w / v)$ BSA (Novero and Asem, 1993) in the presence or absence of different concentrations of EGF or TGF- $\alpha$ for 12 or $24 \mathrm{~h}$. The incubation medium was not changed during the incubation period. The cells were not exposed to fetal calf serum or any other media supplement at any time during these experiments. At the end of the incubation period ( 12 or $24 \mathrm{~h}$ ), the medium, designated as the soluble fibronectin, was removed and stored at $-20^{\circ} \mathrm{C}$ until assayed for fibronectin (cumulative).

The wells were rinsed twice $\left(37^{\circ} \mathrm{C}\right)$ with PBS containing $0.85 \% \mathrm{NaCl}(\mathrm{w} / \mathrm{v})$ and $10 \mathrm{mmol} \mathrm{NaH} \mathrm{PO}_{4} 1^{-1}, \mathrm{pH} 7.4$, and the rinse was discarded. The cells that were attached to the wells were lysed in PBS (PBS-Triton solution) containing 0.5\% Triton $\mathrm{X}-100(\mathrm{v} / \mathrm{v}), 0.5 \mathrm{mg}$ leupeptin $\mathrm{l}^{-1}, 1 \mathrm{mmol}$ EDTA-Na $\mathrm{I}^{-1}$, $0.7 \mathrm{mg}$ pepstatin $\mathrm{I}^{-1}$, and $0.2 \mathrm{mmol}$ PMSF $\mathrm{I}^{-1}$ as described by Novero and Asem (1993). The PBS-Triton solution (granulosa cell lysate) was removed and stored at $-20^{\circ} \mathrm{C}$ until assayed for cell-associated fibronectin (Novero and Asem, 1993). The wells were rinsed again with PBS (the rinse was discarded), and the residual fibronectin content (deposited fibronectin) was measured in the wells (Novero and Asem, 1993).

Total fibronectin produced in each incubation well was calculated as the sum of fibronectin secreted into the medium plus deposited fibronectin plus cell-associated fibronectin. Deposited fibronectin and cell-associated fibronectin are collectively referred to as insoluble fibronectin. The method used for the lysis of cultured granulosa cells did not result in the loss of fibronectin deposited (Novero and Asem, 1993). Medium (soluble) and cell-associated fibronectin were quantified by a competitive ELISA, whereas fibronectin deposited in the wells was quantified with a noncompetitive ELISA (Novero and Asem, 1993). Experiments with EGF or TGF- $\alpha$ were conducted with the same population of cells.

At the beginning of distribution of cells for incubation, aliquots of cell suspension equal to the amount incubated were 


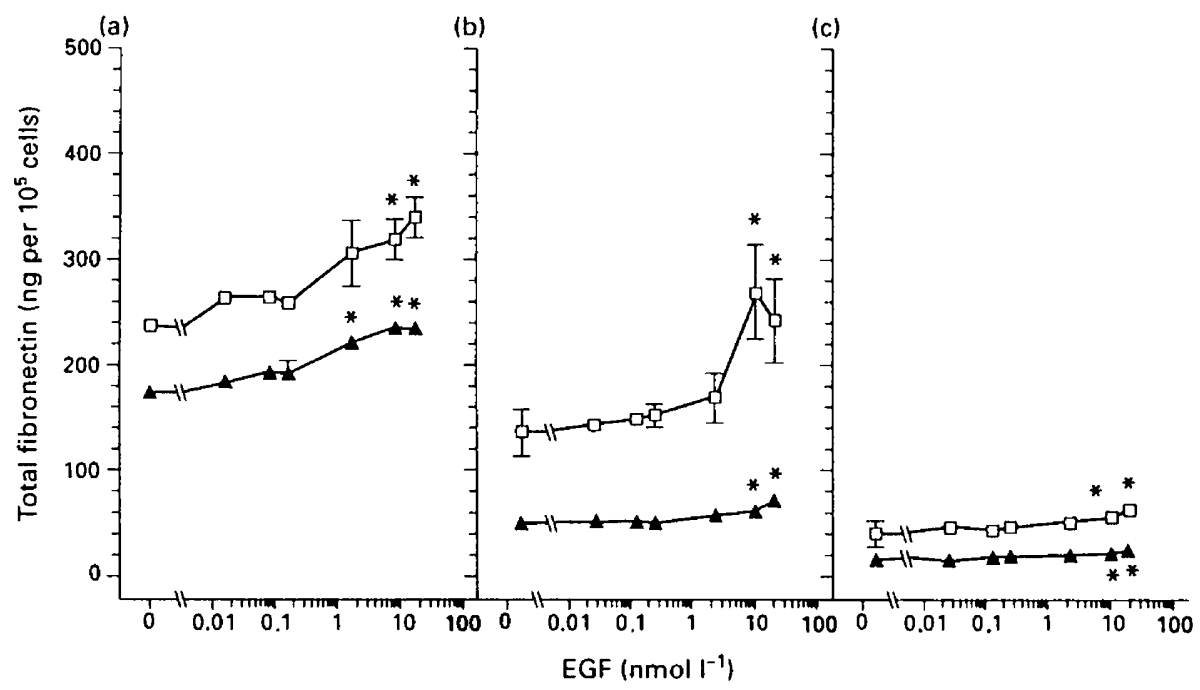

Fig. 1. Effect of epidermal growth factor (EGF) on total fibronectin production by chicken granulosa cells. Granulosa cells obtained from (a) $F_{1}$ (large, mature), (b) $F_{3}$ (third largest, developing), and (c) small yellow follicles were cultured for $(\triangle) 12 \mathrm{~h}$ or $(\square) 24 \mathrm{~h}$ in the absence or presence of EGF. Each point is the mean \pm SE of three separate experiments each conducted in triplicate. Where an error bar is absent, it is smaller than the size of the symbol. ${ }^{*} P<0.05$ compared with the corresponding control value (0 EGF nmol $1^{-1}$ ).

placed in microfuge tubes (three tubes per follicle type). The suspension was centrifuged at the beginning of each incubation period, and the fibronectin content of the supernatant was quantified and defined as the medium fibronectin at the start. The cell pellet was lysed and the amount of fibronectin in the lysate was quantified and designated as the cell-associated (cellular) fibronectin at the start.

\section{Measurement of medium (soluble) fibronectin}

Fibronectin secreted into the incubation medium (soluble fibronectin) was measured by ELISA as described by Novero and Asem (1993). The primary antibody used was raised in rabbits against fibronectin purified from chicken plasma. The interassay and intra-assay coefficients of variation were $10 \%$ and $8 \%$, respectively.

\section{Measurement of cell-associated or deposited (insoluble) fibronectin}

Cell-associated fibronectin was measured after cell lysis using the competitive ELISA as described by Novero and Asem (1993). Fibronectin deposited in incubation wells was measured by noncompetitive ELISA, also described by Novero and Asem (1993). The interassay and intra-assay coefficients of variation were $9 \%$ and $7 \%$, respectively. The type IV collagen used to coat the wells did not crossreact with the anti-chicken fibronectin serum.

\section{Statistical analyses}

Each experiment contained three replicate wells per treatment, and was repeated three times unless stated otherwise. Granulosa cells were obtained from follicles pooled from at least two hens per experiment with each animal donating follicles of the same maturational stage. The amount of fibronectin in the medium at the start was subtracted from the fibronectin in the medium at the end of each incubation. The amount of cell-associated fibronectin at the start was subtracted from cell-associated fibronectin values obtained at the end of each incubation. Data from replicate experiments were analysed by analysis of variance followed by post-hoc Tukey test to determine significant differences among treatment means. The data were also subjected to linear regression analysis to obtain correlation coefficients $(r)$ between EGF or TGF- $\alpha$ concentrations and the amount of fibronectin produced. Differences at a probability level of $P \leq 0.05$ were considered significant.

\section{Results}

The total amount of fibronectin produced (deposited plus medium plus cellular) by $F_{1}, F_{3}$ and small yellow follicle granulosa cells in the absence and presence of EGF or TGF- $\alpha$ increased with advancing stages of follicular maturation (Figs 1 and 2). Addition of EGF for 12 or $24 \mathrm{~h}$ stimulated total fibronectin production by granulosa cells from $\mathrm{F}_{1}, \mathrm{~F}_{3}$ and small yellow follicles (Fig. 1). The correlation coefficients between the concentration of EGF and the total amount of fibronectin produced ranged from 0.63 to 0.84 for all follicle types and periods of incubation, and they were all significant $(P<0.005)$. Similarly, addition of TGF- $\alpha$ for 12 or $24 \mathrm{~h}$ stimulated total fibronectin production by granulosa cells from $\mathrm{F}_{1}, \mathrm{~F}_{3}$ and small yellow follicles (Fig. 2). The correlation coefficients between the concentration of TGF- $\alpha$ and the total amount of fibronectin produced ranged from 0.78 to 0.95 for all follicle types and periods of incubation, and they were all significant $(P<0.005)$. 


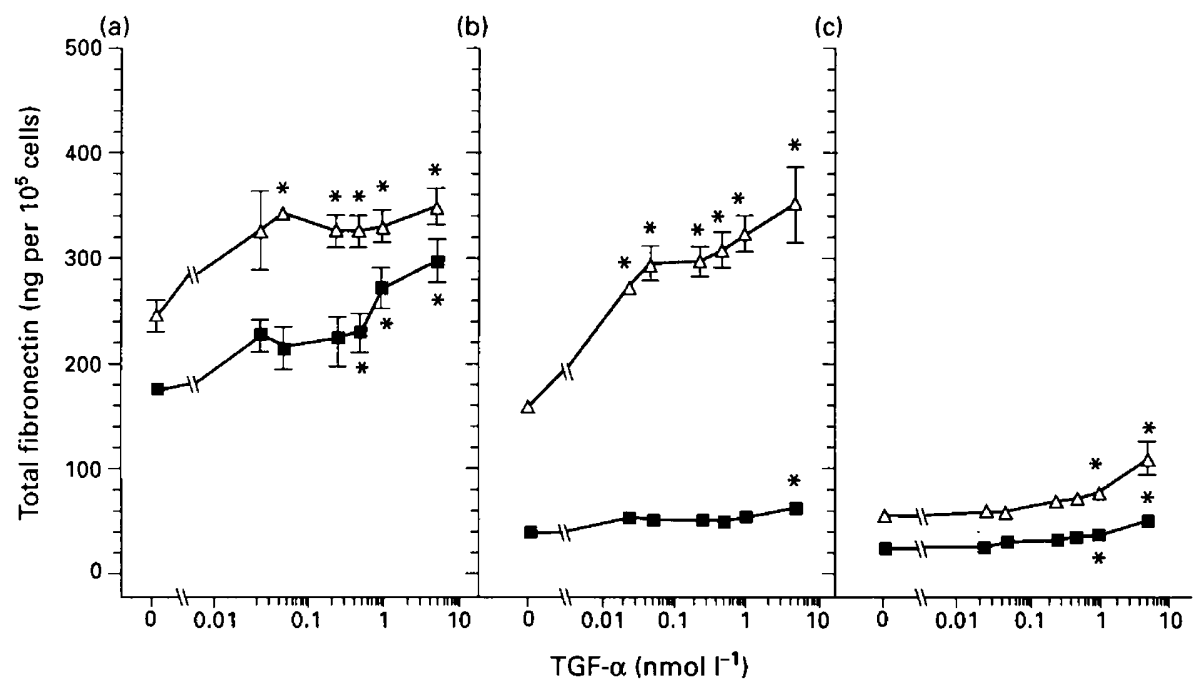

Fig. 2. Effect of transforming growth factor $\alpha$ (TGF- $\alpha$ ) on total fibronectin production by chicken granulosa cells. Granulosa cells obtained from (a) $\mathrm{F}_{\mathrm{I}}$ (large, mature), (b) $\mathrm{F}_{3}$ (third largest, developing), and (c) small yellow follicles were cultured for $12 \mathrm{~h}(\boldsymbol{D})$ or $24 \mathrm{~h}(\Delta)$ in the absence or presence of $\mathrm{TGF}-\alpha$. Each point is the mean $\pm \mathrm{SE}$ of three separate experiments each conducted in triplicate. Where an error bar is absent, it is smaller than the size of the symbol. ${ }^{*} P<0.05$ compared with the corresponding control value ( 0 TGF $\alpha$ nmol $1^{-1}$ ).

\section{Influence of collagen $I V$ on fibronectin distribution}

The influence of type IV collagen (a unique component of basement membranes) on the distribution of fibronectin produced (deposited, medium and cellular) by hen granulosa cells was examined. Granulosa cells were incubated in culture wells coated with type IV collagen. Uncoated plates served as controls.

Deposited fibronectin. The quantity of fibronectin deposited in wells coated with type IV collagen or in uncoated wells by unstimulated (no EGF or TGF- $\alpha$ added) $F_{1}, F_{3}$ or small yellow follicle granulosa cells increased concomitantly with advancing follicular development (Figs 3 and 4). The amount of fibronectin deposited by each cell type (unstimulated) was greater $(P<0.05)$ in collagen-coated wells than in uncoated wells (Figs 3 and 4). Addition of EGF to cells in uncoated wells increased the quantity of deposited fibronectin by $\mathrm{F}_{1}, \mathrm{~F}_{3}$ and small yellow follicle granulosa cells (the value of $r$ was between 0.88 and $0.99 ; P<0.01)$. EGF also increased the amount of fibronectin deposited in collagen-coated wells by $F_{1}, F_{3}$ and small yellow follicle granulosa cells ( $r$ was between 0.86 and $0.97 ; P<0.05$ ).

Addition of TGF- $\alpha$ to granulosa cells in uncoated wells increased the quantity of deposited fibronectin by $F_{1}, F_{3}$ and small yellow follicle granulosa cells $(r$ was between 0.87 and $0.95 ; P<0.05)$. Similarly, TGF- $\alpha$ increased the quantity of fibronectin deposited in collagen-coated wells by $\mathrm{F}_{1}, \mathrm{~F}_{3}$ and small yellow follicle granulosa cells ( $r$ was between 0.75 and 0.97; $P<0.05$ ). The amount of fibronectin deposited after addition of EGF or TGF- $\alpha$ was greater $(P<0.05)$ in each cell type in collagen-coated wells than in uncoated wells (Figs 3 and 4). The quantity of fibronectin deposited by granulosa cells following exposure to EGF and TGF- $\alpha$ was less $(P<0.05)$ for cells obtained from small yellow follicles than from $F_{1}$ and $F_{3}$ follicles (Figs 3 and 4).
Fibronectin in the medium. The amount of fibronectin secreted into the incubation medium by unstimulated (no EGF or TGF- $\alpha$ added) $F_{1}, F_{3}$ and small yellow follicle cells in wells coated with type IV collagen or in uncoated wells increased with advanced stages of follicular maturation (Figs 5 and 6). Addition of EGF increased the quantity of fibronectin secreted into the incubation medium in uncoated wells by granulosa cells obtained from $\mathrm{F}_{1}, \mathrm{~F}_{3}$ and small yellow follicles ( $r$ was between 0.81 and $0.97 ; P<0.05$ ). Similarly, EGF increased the amount of fibronectin secreted into the incubation medium in collagen-coated wells by $\mathrm{F}_{1}, \mathrm{~F}_{3}$ and small yellow follicle granulosa cells ( $r$ was between 0.86 and $0.95 ; P<0.05$ ) (Fig. 5). Like EGF, TGF- $\alpha$ increased the quantity of fibronectin secreted into the medium in uncoated wells by $\mathrm{F}_{1}, \mathrm{~F}_{3}$ and small yellow follicle granulosa cells ( $r$ was between 0.76 and $0.83 ; P<0.05$ ) (Fig. 6). TGF- $\alpha$ also increased the amount of fibronectin secreted into the medium in collagen-coated wells by $\mathrm{F}_{1}, \mathrm{~F}_{3}$ and small yellow follicle granulosa cells $(r$ was between 0.88 and 0.95; $P<0.01$ ) (Fig. 6). Unlike deposited fibronectin, the quantities of fibronectin secreted into the medium in collagencoated wells (in the presence and absence of the growth factors) were not different $(P>0.05)$ from those in the uncoated wells (Figs 5 and 6). Fibronectin secreted into the medium following exposure to EGF and TGF- $\alpha$ was less $(P<0.05)$ from cells obtained from small yellow follicles than from cells obtained from $F_{1}$ and $F_{3}$ follicles (Figs 5 and 6).

Cellular (cell-associated) fibronectin. The quantity of cellular fibronectin produced by unstimulated $\mathrm{F}_{1}$ granulosa cells (no EGF and TGF- $\alpha$ ) was less $(P<0.05)$ than that produced by $F_{3}$ or small yellow follicle granulosa cells (Figs 7 and 8 ). EGF increased the quantity of cellular fibronectin (Fig. 7) in $\mathrm{F}_{1}, \mathrm{~F}_{3}$ and small yellow follicle granulosa cells in uncoated wells $(r$ was between 0.90 and $0.99 ; \quad P<0.005$ ). Similarly, EGF 


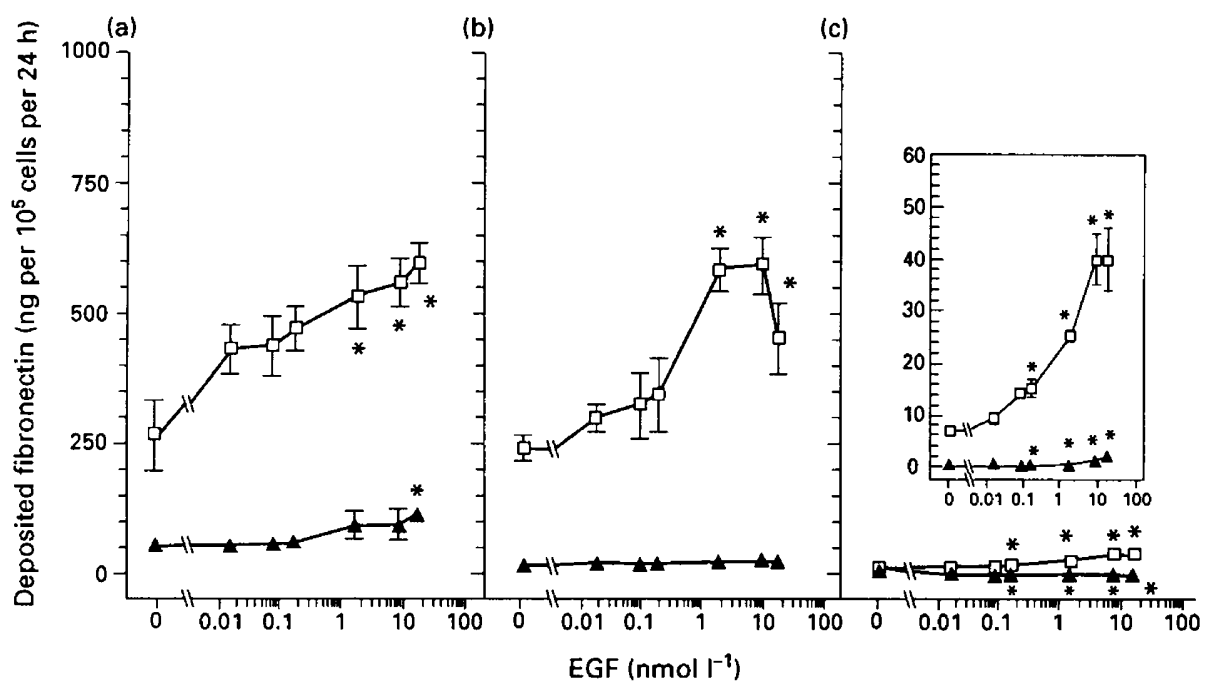

Fig. 3. Influence of type IV collagen on stimulation of fibronectin deposition by epidermal growth factor (EGF) in chicken granulosa cells. Granulosa cells obtained from (a) $F_{1}$ (large, mature), (b) $F_{3}$ (third largest, developing), and (c) small yellow follicles were cultured for $24 \mathrm{~h}$ in wells coated with type IV collagen ( $\square$ ) or in uncoated wells $(\Lambda)$ in the absence or presence of EGF. Inset: data for small yellow follicle granulosa cells are presented on an expanded scale. Each point is the mean \pm SE of two separate experiments each conducted in triplicate. Where an error bar is absent, it is smaller than the size of the symbol. ${ }^{*} P<0.05$ compared with the corresponding control value $\left(0 \mathrm{EGF}\right.$ nmol $\left.1^{-1}\right)$.

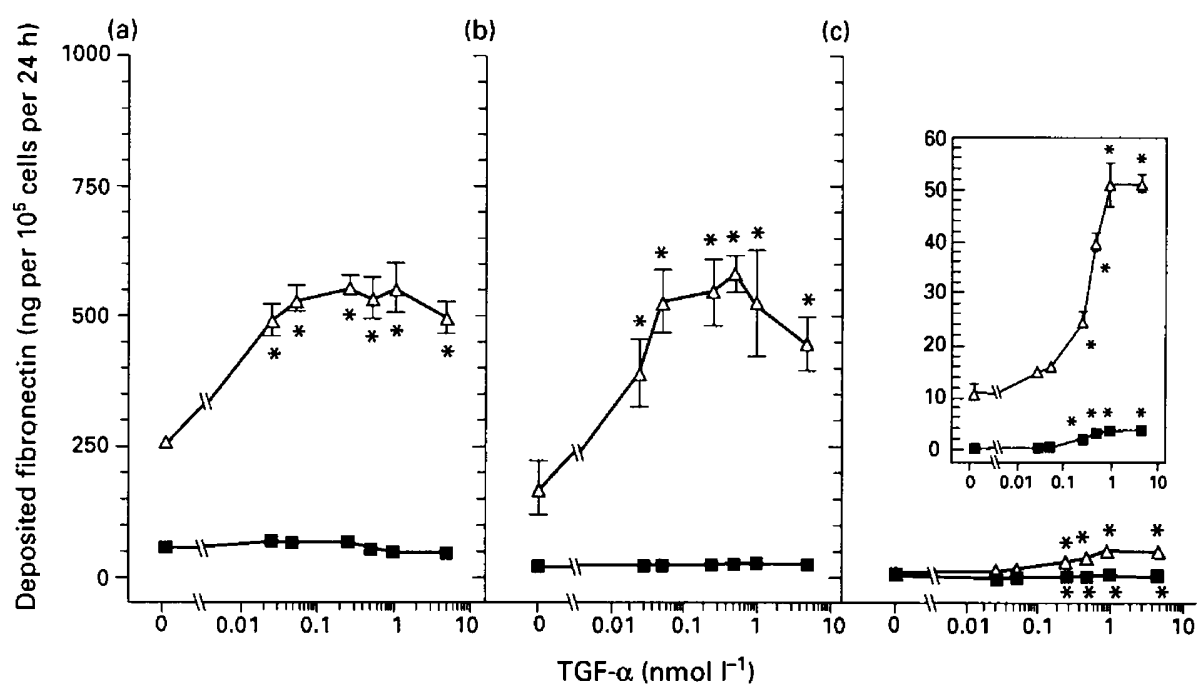

Fig. 4. Influence of type IV collagen on stimulation of fibronectin deposition by transforming growth factor $\alpha$ (TGF- $\alpha$ ) in chicken granulosa cells. Granulosa cells obtained from (a) $\mathrm{F}_{I}$ (large, mature), (b) $F_{3}$ (third largest, developing), and (c) small yellow follicles were cultured for $24 \mathrm{~h}$ in wells coated with type IV collagen $(\Delta)$ or in uncoated wells $(\boldsymbol{\square})$ in the absence or presence of TGF- $\alpha$. Inset: data for small yellow follicle granulosa cells are presented on an expanded scale. Each point is the mean $\pm \mathrm{SE}$ of two separate experiments each conducted in triplicate. Where an error bar is absent, it is smaller than the size of the symbol. ${ }^{*} P<0.05$ compared with the corresponding control value ( 0 TGF- $\alpha$ nmol $1^{-1}$ ).

increased the quantity of cellular fibronectin (Fig. 7) in $\mathrm{F}_{1}, \mathrm{~F}_{3}$ and small yellow follicle granulosa cells in collagen-coated wells ( $r$ was between 0.89 and $0.98 ; P<0.01$ ). TGF- $\alpha$ caused an increase in the quantity of cell-associated fibronectin (Fig. 8) in $\mathrm{F}_{1}, \mathrm{~F}_{3}$ and small yellow follicle granulosa cells in uncoated wells
( $r$ was between 0.92 and $0.98 ; P<0.005$ ). Likewise, TGF- $\alpha$ increased the quantity of fibronectin associated (Fig. 8) with $\mathrm{F}_{1}$, $\mathrm{F}_{3}$ and small yellow follicle granulosa cells in collagen-coated wells $(r$ was between 0.91 and $0.96 ; P<0.005)$. The amount of fibronectin that was associated with granulosa cells following 


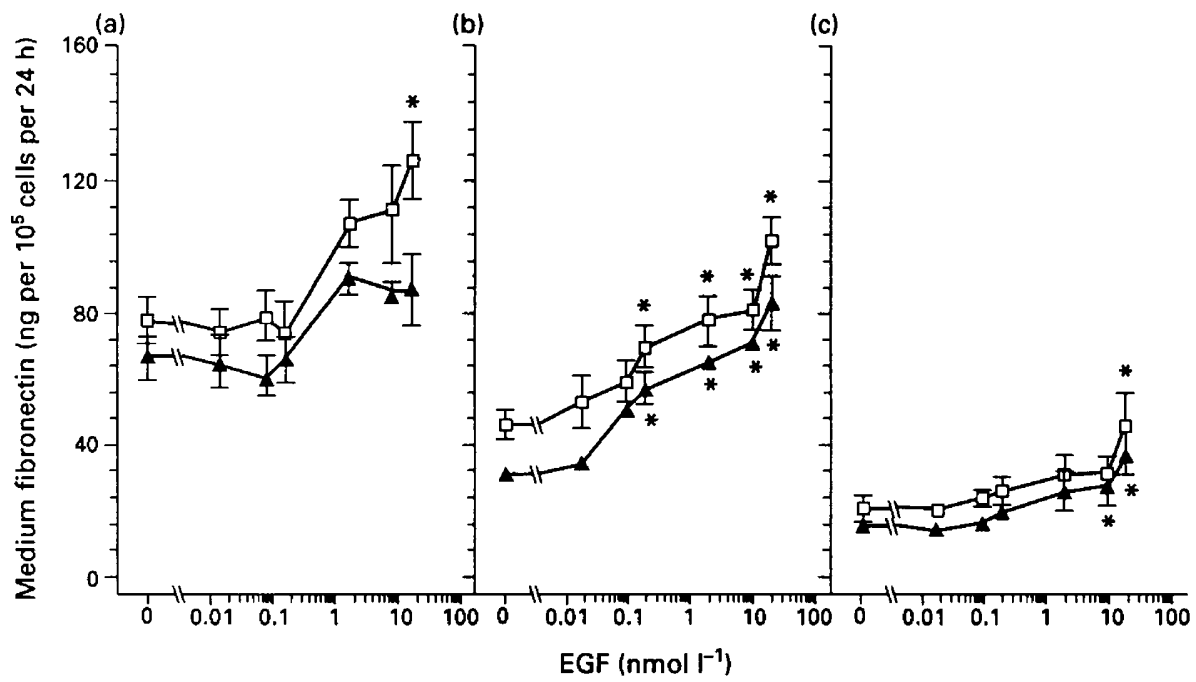

Fig. 5. Influence of type IV collagen on stimulation of soluble (medium) fibronectin production by epidermal growth factor (EGF) in chicken granulosa cells. Granulosa cells obtained from (a) $F_{1}$ (large, mature), (b) $\mathrm{F}_{3}$ (third largest, developing) and (c) small yellow follicles were cultured for $24 \mathrm{~h}$ in wells coated with type IV collagen $(\square)$ or in uncoated wells $(\mathbf{\Lambda})$ in the absence or presence of EGF. Each point is the mean \pm SE of two separate experiments each conducted in triplicate. Where an error bar is absent, it is smaller than the size of the symbol. ${ }^{*} P<0.05$ compared with the corresponding control value (O EGF nmol $1^{-1}$ ).

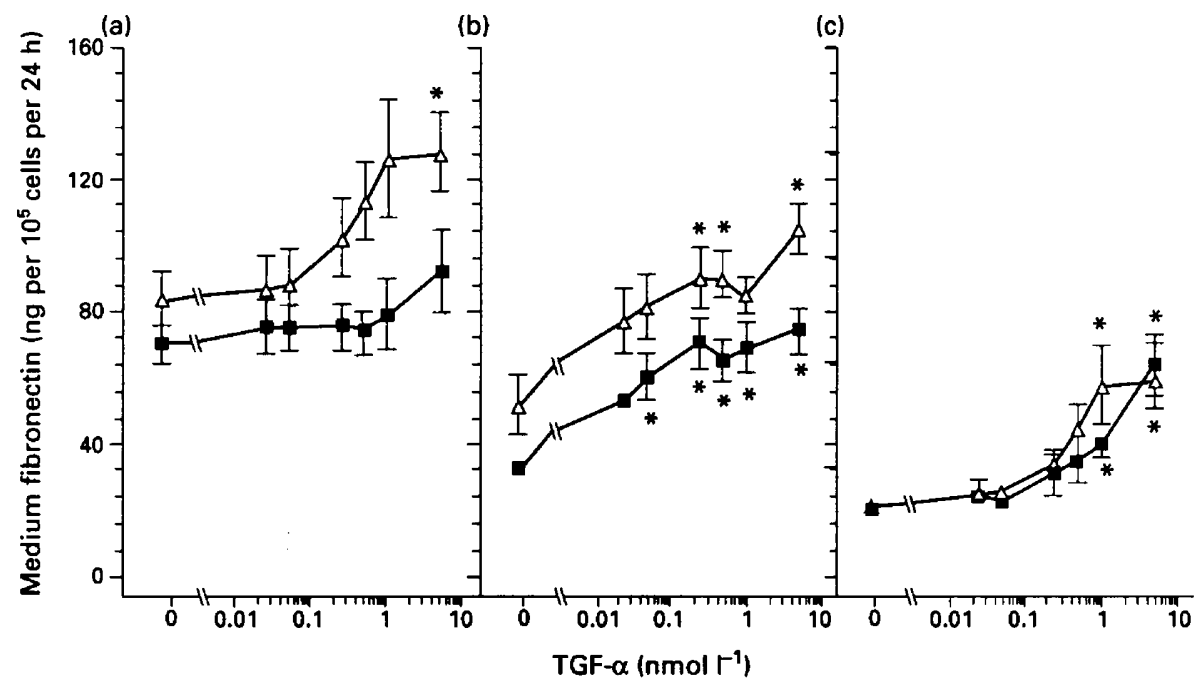

Fig. 6. Influence of type IV collagen on stimulation of soluble (medium) fibronectin production by transforming growth factor $\alpha$ (TGF- $\alpha$ ) in chicken granulosa cells. Granulosa cells obtained from (a) $\mathrm{F}_{1}$ (large, mature), (b) $\mathrm{F}_{3}$ (third largest, developing), and (c) small yeliow follicles were cultured for $24 \mathrm{~h}$ in wells coated with type IV collagen $(\Delta)$ or in uncoated wells $(\boldsymbol{\omega})$ in the absence or presence of TGF- $\alpha$. Each point is the mean \pm SE of two separate experiments each conducted in triplicate. Where an error bar is absent, it is smaller than the size of the symbol. ${ }^{*} P<0.05$ compared with the corresponding control value (no TGF added).

exposure to EGF and TGF- $\alpha$ was greater $(P<0.05)$ in cells obtained from $\mathrm{F}_{3}$ and small yellow follicles than in cells from $\mathrm{F}_{1}$ follicles (Figs 7 and 8). Like fibronectin secreted into the medium, the quantities of cellular fibronectin in collagen-coated wells (in the presence and absence of the growth factors) were not different $(P>0.05)$ from the amount of cellular fibronectin in uncoated wells (Figs 7 and 8).

The effect of collagen IV on the total amount of fibronectin produced (deposited, medium and cellular) was calculated. Because of its large effect on deposited fibronectin, there were 


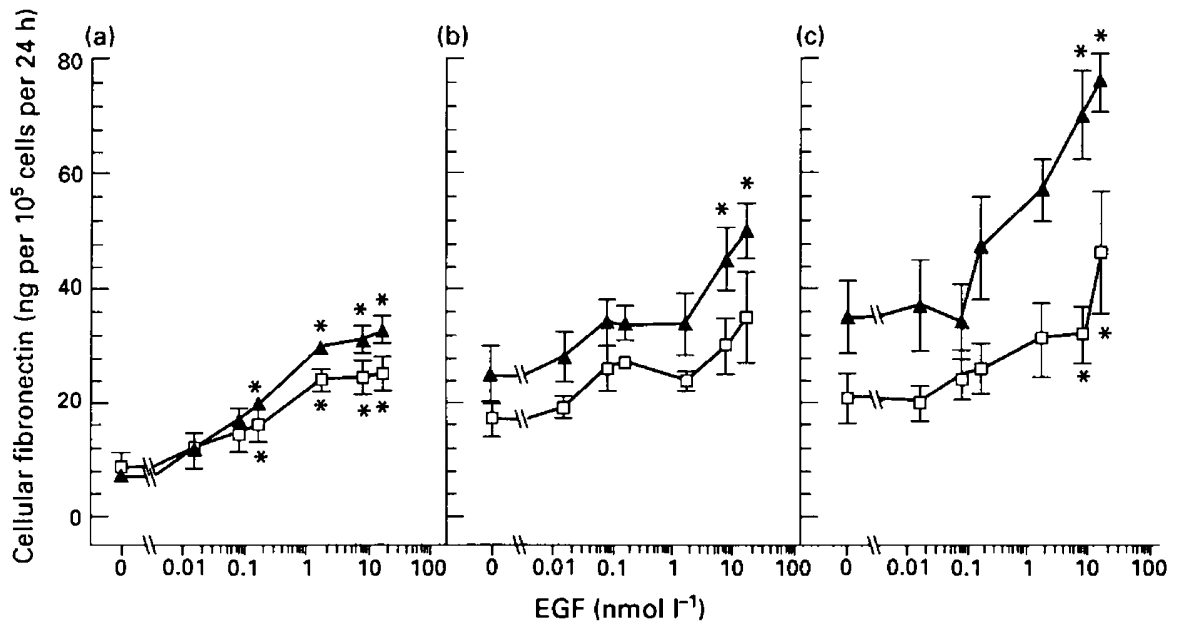

Fig. 7. Influence of type IV collagen on stimulation of cellular fibronectin production by epidermal growth factor (EGF) in chicken granulosa cells. Granulosa cells obtained from (a) $F_{1}$ (large, mature), (b) $\mathrm{F}_{3}$ (third largest, developing) and (c) small yellow follicles were cultured for $24 \mathrm{~h}$ in wells coated with type IV collagen $(\square)$ or in uncoated wells $(\Lambda)$ in the absence or presence of EGF. Each point is the mean $\pm \mathrm{SE}$ of two separate experiments each conducted in triplicate. Where an error bar is absent, it is smaller than the size of the symbol. ${ }^{*} P<0.05$ compared with the corresponding control value (no EGF added).

(a)

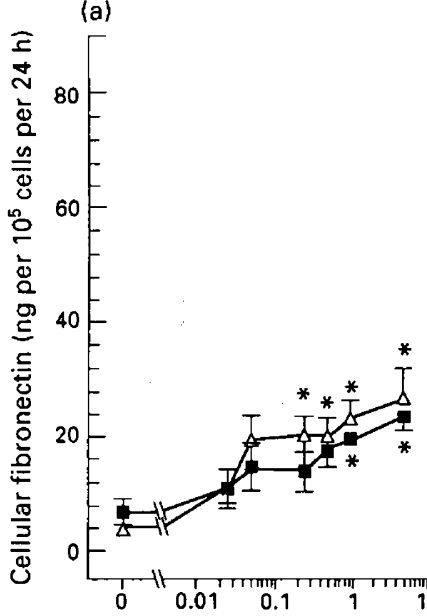

(b)

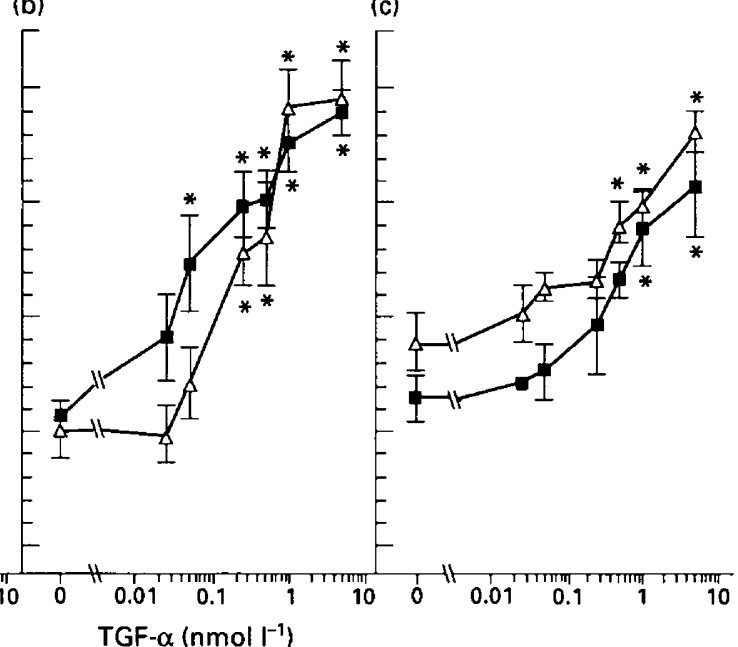

Fig. 8. Influence of type IV collagen on stimulation of cellular fibronectin production by transforming growth factor $\alpha$ (TGF- $\alpha$ ) in chicken granulosa cells. Granulosa cells obtained from (a) $\mathrm{F}_{\mathrm{I}}$ (large, mature), (b) $\mathrm{F}_{3}$ (third largest, developing) and (c) small yellow follicles were cultured for $24 \mathrm{~h}$ in wells coated with type IV collagen $(\Delta)$ or in uncoated wells $(\boldsymbol{D})$ in the absence or presence of TGF- $\alpha$. Each point is the mean \pm SE of two separate experiments each conducted in triplicate. Where an error bar is absent, it is smaller than the size of the symbol. ${ }^{*} P<0.05$ compared with the corresponding control value (0 TGF- $\alpha$ nmol $1^{-1}$ ).

greater total quantities of fibronectin in culture wells coated with type IV collagen than in uncoated wells (data not shown).

\section{Discussion}

The present results demonstrate that EGF and TGF- $\alpha$ stimulate fibronectin production by chicken granulosa cells. The stimu- lated production of fibronectin was reflected in each of the three compartments (medium, cell-associated and deposited) that make up total fibronectin. Stimulation of fibronectin deposition and secretion into medium by EGF and TGF- $\alpha$ in the present study increased with advancing stage of follicular development; however, cell-associated fibronectin stimulated by these factors was lower in granulosa cells isolated from the most mature $\left(\mathrm{F}_{1}\right)$ follicles. Similar observations were made for 
the effects of FSH and 8-bromo-cyclic AMP on fibronectin production by chicken granulosa cells (Asem and Novero, 1993a; Novero and Asem, 1993).

Fibronectin produced by a wide variety of cells is incorporated into matrix material in vitro (Ruoslahti et al., 1981; Hynes and Yamada, 1982), and the results of the present study confirm the recent reports that chicken granulosa cells produce and deposit fibronectin in vitro (Asem and Novero, 1993a; Novero and Asem, 1993). In view of the fact that type IV collagen is a major component of basement membranes with which other components of this structure interact (Timpl, 1989; Yurchenco and Schittny, 1990), the present data suggest that fibronectin produced by chicken granulosa cells can interact with collagen IV in the formation of basal lamina. Fibronectin has been immunolocalized to the basal lamina of ovarian follicles of domestic hens (Yoshimura et al., 1985; Callebaut et al., 1988). Although it remains to be proved, the quantity of fibronectin deposited by $\mathrm{F}_{1}, \mathrm{~F}_{3}$ and small yellow follicles of granulosa cells in collagen-coated wells may be a reflection of the relative contribution of fibronectin by chicken granulosa cells at a particular stage of development to the formation of basal lamina in vivo. It is noteworthy that the maturation of the chicken ovarian follicle is associated with a marked increase in the size of the oocyte and an increase in the number of granulosa cells (Gilbert et al., 1980). This growth must be accompanied by an increase in the production and deposition of various extracellular matrix proteins to maintain the continuity of the basal lamina.

The reason for increased deposition of fibronectin in wells coated with type IV collagen is not known. However, since it is a major (naturally occurring) component of basement membranes, collagen IV may increase the deposition of fibronectin by interacting with and sequestering fibronectin. Clearly, additional studies are needed to elucidate the exact mechanism by which collagen IV influences fibronectin deposition by chicken granulosa cells. The possibility remains that the effect of collagen IV on fibronectin deposition is not specific but is a general feature of extracellular matrix proteins (collagenous and non-collagenous) in vitro. Future studies with different types of collagen (for example type I or type III collagen) should provide information concerning the specificity of collagen IV on fibronectin deposition by chicken granulosa cells in vitro.

Fibronectin production in a number of cell types is stimulated by EGF (Chen et al., 1977; Thome et al., 1987; Bade and Feindler, 1988). It induces fibronectin gene transcription in AKR-2B mouse embryo fibroblasts (Blatti et al., 1988) and in rat liver epithelial cells (Seebacher et al., 1988). The source of EGF that may influence chicken granulosa cell function in vivo is unknown. EGF or EGF-like substances are produced by the mammalian ovary (Rall et al., 1985; Skinner et al., 1987; Roy and Greenwald, 1990; Maruo et al., 1993). Furthermore, TGF- $\alpha$ is also produced by the mammalian ovary (Kudlow et al., 1987; Lobb et al., 1989). Whether these growth factors are produced by the chicken ovary remains to be determined. However, the observations that EGF (mammalian) regulates a number of chicken granulosa cell functions (Pulley and Marrone, 1986; Yoshimura and Tamura, 1988; Tilly and Johnson, 1990; Li et al., 1991) support the notion that this growth factor is a regulator of hen ovarian function.
It is noteworthy that the primary structure of the chicken EGF receptor has been shown to show considerable similarity to that of the human EGF receptor (Lax et al., 1988). Human TGF- $\alpha$ binds the chicken EGF receptor with slightly higher affinity than the human EGF receptor (Lax et al., 1988). The effects of TGF- $\alpha$ may be mediated by the mechanisms that transduce the action of EGF because of the structural similarity between TGF- $\alpha$ and EGF (Marquardt et al., 1984). In addition, TGF- $\alpha$ binds to the EGF receptor in the plasma membrane (Massague, 1983; Marquardt et al., 1984) and induces biological responses similar to those caused by EGF (Derynck, 1986). The growth factors (EGF and TGF- $\alpha$ ) had no effect on number of granulosa cells in the present experiments (data not shown). It has been demonstrated that EGF, LH and FSH have no effect on the number of chicken granulosa cells in vitro until after 7 days in culture (Yoshimura and Tamura, 1988). The effects of EGF and TGF- $\alpha$ on fibronectin production (in the present studies) by chicken granulosa cells that were incubated for 12 or $24 \mathrm{~h}$ (in serum-free medium) may not therefore be ascribed to changes in the number of granulosa cells.

In summary, hen granulosa cells produce and deposit fibronectin. The deposition of fibronectin is greater in wells coated with type IV collagen (a unique component of basal lamina). Both EGF and TGF- $\alpha$ stimulated soluble (medium) and insoluble (deposited and cell-associated) fibronectin production by the cells. These data indicate that during follicular development, EGF and TGF- $\alpha$ in combination with collagen can increase fibronectin deposition in the extracellular matrix (for example basal lamina) by granulosa cells. The deposited fibronectin could be one of the factors that cause the reported changes in the morphology of granulosa cells during follicular development. In the chicken ovarian follicle, granulosa cells become flattened with advancing follicular development (Gilbert et al., 1980).

This research was supported partly by National Institutes of Health grant No. HD-27354, and partly by funds from the School of Veterinary Medicine, Purdue University, West Lafayette, ID, USA.

\section{References}

Adashi EY, Resnick CE and Twardzik DR (1987) Transforming growth factor $\boldsymbol{\alpha}$ attenuates the acquisition of aromatase activity by cultured rat granulosa cells Joumal of Cellular Biochemistry 33 1-13

Asem EK and Novero RP (1993a) Influence of follicular maturation on the deposition of fibronectin by chicken granulosa cells in vitro: Effect of 8-bromo cyclic AMP Domestic Animal Endocrinology 10 219-228

Asem EK and Novero RP (1993b) Chicken gonadotropin-releasing hormones enhance soluble and insoluble fibronectin production by granulosa cells of the domestic fowl in vitro Poultry Science 72 1961-1971

Asem EK, Lintner F, Biellier HV, Burke WH and Hertelendy F (1983) Comparison of turkey luteinizing hormone and ovine $\mathrm{LH}$-induced progesterone production in granulosa cells of the turkey (Meleagris gallopavo) and of the domestic fow! (Gallus domesticus) General and Comparative Endocrinology 52 445-451

Asem EK, Carnegie JA and Tsang BK (1992) Fibronectin production by chicken granulosa cells in vitro: effect of follicular development Acta Endocrinologica $127466-470$

Asem EK, Conkright MD and Novero RP (1994) Progesterone stimulates fibronectin production by chicken granulosa cells in vitro European Journal of Endocrinology 130 159-165

Bade EG and Feindler S (1988) Liver epithelial cell migration induced by epidermal growth factor or transforming growth factor alpha is associated with changes in the gene expression of secreted proteins In Vitro Cell Developmental Biology 24 149-154 
Bagavandoss M, Midgley AR, Jr and Wicha M (1983) Developmental changes in the ovarian follicular basal lamina detected by immunofluorescence and electron microscopy Joumal of Histochemistry and Cytochemistry 31633-640

Bahr JM, Wang SC, Huang MY and Calvo FO (1983) Steroid concentrations in isolated theca and granulosa layers of preovulatory follicles during the ovulatory cycle of the domestic hen Biology of Reproduction 29 326-334

Bendell JI and Dorrington JH (1990) Epidermal growth factor influences growth and differentiation of rat granulosa cells Endocrinology $127533-540$

Bernath VA, Muro AF, Vitullo AD, Bley MA, Baranao JL and Kornblihtt AR (1990) Cyclic AMP inhibits fibronectin gene expression in a newly developed granulosa cell line by a mechanism that suppresses cAMP-responsive element-dependent transcriptional activation Journal of Biological Chemistry 265 18219-18226

Blatti SP, Foster DN, Ranganathan G, Moses HL and Getz MJ (1988) Induction of fibronectin gene transcription and mRNA is a primary response to growthfactor stimulation of AKR-2B cells Proceedings of the National Academy of Sciences USA 85 1119-1123

Callebaut M, Harrison F and Van Nassauw L (1988) Fibronectin immunoreactivity in the avian ovarian follicular wall Medical Science Research 16 131-132

Carnegie JA (1990) The secretion of fibronectin by rat granulosa cells occurs primarily during early follicular development. Journal of Reproduction and Fertility 89 579-589

Chen LB, Gudor RC, Sun TT, Chen AB and Mossesson MW (1977) Control of a cell surface major glycoprotein by epidermal growth factor. Science 197 776-778

Clark RAF, Dvorak HF and Colvin RB (1981) Fibronectin in delayed-type hypersensitivity skin reactions: associations with vessel permeability and endothelial cell activation Joumal of Immunology 126 787-793

Critchley DR, England MA, Wakely J and Hynes RO (1979) Distribution of fibronectin in the ectoderm of gastrulating chick embryos Nature $\mathbf{2 8 0}$ 498-500

Derynck R (1986) Transforming growth factor- $\alpha$ : structure and biological actions Journal of Cellular Biochemistry 32 293-304

Dorrington JH and Skinner MK (1986) Cytodifferentiation of granulosa cells induced by gonadotropin-releasing hormone promotes fibronectin secretion Endocrinology 118 2065-2071

Etches RJ and Duke CE (1984) Progesterone, androstenedione and oestradiol content of the theca and granulosa tissues of the four largest ovarian follicles during the ovulatory cycle of the hen (Gallus domesticus) Journal of Endocrinology 103 71-76

Fyrand O (1980) Studies on fibronectin in the skin. IV. Indirect immunofluorescence studies in lupus erythematosus British Journal of Dermatology 102 $167-171$

Gilbert AB, Evans AJ, Perry MM and Davidson MH (1977) A method for separating the granulosa cells, the basal lamina and the theca of the preovulatory ovarian follicle of the domestic fowl (Gallus domesticus) Journal of Reproduction and Fertility $\mathbf{5 0}$ 179-181

Gilbert AB, Hardie MA, Perry MM, Dick HR and Wells JW (1980) Cellular changes in the granulosa layer of the maturing ovarian follicle of the domestic fowl British Poultry Science 21 257-263

Grimwood RE, Huff JC, Harbell J and Clark RAF (1984) The source of fibronectin in basal cell epithelioma Journal of Investigative Dermatology 82 145-149

Grinnell F, Billingham RE and Burgess L (1981) Distribution of fibronectin during wound healing in vivo Journal of Investigative Dermatology 76 181-189

Hammond JM and English HF (1987) Regulation of deoxyribonucleic acid synthesis in cultured porcine granulosa cells by growth factors and hormones Endocrinology 120 1039-1046

Hammond RW, Burke WH and Hertelendy F (1981) Influence of follicular maturation on progesterone release in chicken granulosa cells in response to turkey and ovine gonadotropins Biology of Reproduction 24 1048-1055

Hsueh AJW, Welsh TH, Jr and Jones PBC (1981) Inhibition of ovarian and testicular steroidogenesis by epidermal growth factor Endocrinology 108 2002-2009

Hynes RO and Yamada KM (1982) Fibronectins: multifunctional modular glycoproteins Journal of Cell Biology 95 369-377

Kimata K, Foidart JM, Pennypacker JP, Kleinman HK, Martin GR and Hewitt AT (1982) Immunofluorescence localization of fibronectin in chondrosarcoma cartilage matrix Cancer Research 42 2384-2391

Klebe RJ (1974) Isolation of a collagen-dependent cell attachment factor Nature $250248-251$
Kudlow JF, Korbi AF, Purchio MS, Twardzik DR, Hernandez ER, Asa SL and Adashi EY (1987) Ovarian transforming growth factor- $\alpha$ gene expression: immunohistochemical localization to the theca-interstitial cells Endocrinology 121 1577-1579

Kurkinen M, Vaheri A, Roberts PJ and Steinman S (1980) Sequential appearance of fibronectin and collagen in experimental granulation tissue Laboratory Investigation 43 47-57

Lax I, Johnson A, Howk R. Sap J, Bellot F, Winkler M, Ullrich A, Vennstrom B, Schlessinger J and Givol D (1988) Chicken epidermal growth factor (EGF) receptor: cDNA cloning, expression in mouse cells, and differential binding of EGF and transforming growth factor alpha Molecular and Cellular Biology 8 1970-1978

Li Z and Johnson AL (1993) Regulation of cytochrome P450 17a-hydroxylase mRNA and enzyme activity in granulosa cells from immature follicles of the hen Biology of Reproduction 46 463-469

Li M, Morley P, Asem EK and Tsang BK (1991) Epidermal growth factor elevates intracellular $\mathrm{pH}$ in chicken granulosa cells Endocrinology 129 656-662

Linder E, Vaheri A, Rouslahti E and Wartiovaara J (1975) Distribution of fibroblast surface antigen in the developing chick embryo Journal of Experimental Medicine 142 41-49

Lobb JJ, Kobrin MS, Kudlow JE and Dorrington JH (1989) Transforming growth factor- $\alpha$ in the adult bovine ovary: identification in growing ovarian follicles Biology of Reproduction 40 1087-1093

Marquardt H, Hunkapiller MW, Hood LE and Todaro GJ (1984) Rat transforming growth factor type I: structure and relation to epidermal growth factor Science 223 1079-1082

Marrone BL and Hertelendy F (1983) Steroidogenesis by avian ovarian cells: effects of LH and substrate availability American Journal of Physiology 244 487-493

Maruo T, Ladines-Llave CA, Samoto T, Matsuo H, Manalo AS, Ito $H$ and Motsizuki $M$ (1993) Expression of epidermal growth factor and its receptor in the human ovary during follicular growth and regression Endocrinology 132 924-931

Massague J (1983) Epidermal growth factor-like transforming growth factor. II. Interaction with epidermal growth factor receptors in human placenta membranes and A431 cells Journal of Biological Chemistry $25813614-$ 13620

May JF, Frost JP and Schomberg DW (1988) Differential effects of epidermal growth factor, somatomedin-C/insulin-like growth factor I, and transforming growth factor $\beta$ on porcine granulosa cell deoxyribonucleic acid synthesis and cell proliferation Endocrinology 123 168-179

Novero RP and Asem EK (1993) Follicle-stimulating hormone-enhanced fibronectin production by chicken granulosa cells is influenced by follicular development Poultry Science 72 709-729

Pearlstein E (1976) Plasma membrane glycoprotein which mediates adhesion of fibroblasts to collagen Nature 262 497-500

Perry MM, Gilbert AB and Evans AJ (1978) The structure of the germinal disc region of the hen's ovarian follicle during the rapid growth phase Journal of Anatomy 127 379-392

Pulley DD and Marrone BL (1986) Inhibitory action of epidermal growth factor on progesterone biosynthesis in hen granulosa cells during short term culture: two sites of action Endocrinology 118 2284-2291

Rall LB, Scott J, Bell G, Crawford RJ, Penchow JD, Nill HD and Coughlan JP (1985) Mouse pre-pro epidermal growth factor synthesis by the kidney and other tissues Nature 313 228-23I

Robinson FE and Etches RJ (1986) Ovarian steroidogenesis during follicular maturation in the domestic fowl (Gallus domesticus) Biology of Reproduction 35 1096-1105

Roy SK and Greenwald GS (1990) Immunohistochemical localization of epidermal growth factor-like activity in the hamster ovary with a polyclonal antibody Endocrinology 126 1309-1317

Roy SK and Greenwald GS (1991) In vitro effects of epidermal growth factor, insulin-like growth factor-l, fibroblast growth factor, and follicle stimulating hormone on hamster follicular deoxyribonucleic acid synthesis and steroidogenesis Biology of Reproduction 44 889-896

Ruoslahti E, Engvall E and Hayman EG (1981). Fibronectin: current concepts of its structure and function Collagen Research 1 95-128

Savion N and Gospodarowicz D (1980) Patterns of cellular peptide synthesis by cultured bovine granulosa cells Endocrinology 107 1798-1807

Schomberg DW, May JV and Mondschein JS (1983) Interaction between hormones and growth factors in the regulation of granulosa cell differentiation in vitro Journal of Steroid Biochemistry 19 291-299 
Seebacher T, Manske M, Kornblihtt AR and Bade EG (1988) Cellular fibronectin is induced by epidermal growth factor but not by dexamethasone or cyclic AMP in rat liver epithelial cells FEBS Letters 239 113-116

Skinner KM, McKeracher HL and Dorrington JH (1985) Fibronectin as a marker of granulosa cell cytodifferentiation Endocrinology 117 886-892

Skinner KM, Lobb D and Dorrington JH (1987) Ovarian thecal/interstitial cells produce an epidermal growth factor-like substance Endocrinology 121 1892-1899

Thorne HJ, Jose DG, Zhang HY, Dempsey PJ and Whitehead RH (1987) Epidermal growth factor stimulates the synthesis of cell-attachment proteins in the human breast cancer cell line PMC42 International Journal of Cancer 40 207-212

Tilly JL and Johnson AL (1990) Effect of several growth factors on plasminogen activator activity in granulosa and theca cells of the domestic hen Poultry Science $69292-299$

Timpl R (1989) Structure and biological activity of basement membrane proteins European Journal of Biochemistry 180 487-502
Yoshimura $Y$ and Okamoto T (1991) Localization of fibronectin in the bovine ovary Animal Science and Technology (Japan) 62 529-532

Yoshimura Y and Tamura T (1988) Effects of gonadotropins, steroid hormones and epidermal growth factor on the in vitro proliferation of chicken granulosa cells Poultry Science $67814-818$

Yoshimura $Y$ and Tamura T (1991) Cyclic adenosine monophosphate promotes the proliferation of chicken granulosa cells in culture General and Comparative Endocrinology 84 222-227

Yoshimura Y, Okamoto T and Tamura T (1985) Immunohistochemical observations on the distribution of fibronectin in the hen's ovarian follicles Japanese Poultry Science 22 274-278

Yurchenco PD and Schittny JC (1990) Molecular architecture of basement membranes Federation of American Society of Experimental Biologists Journal 4 $1577-1590$ 